\title{
An exploration study on factors influencing on market orientation: A case study of tourism industry
}

\author{
Hamid Bagheri*, Masoud Hassanabadi, Fatemeh Isapour and Hamed Asgari
}

Department of Management, Islamic Azad University, South Tehran Branch, Tehran, Iran

\begin{tabular}{|c|c|}
\hline C H R O N I C L E & A B S T R A T \\
\hline $\begin{array}{l}\text { Article history: } \\
\text { Received February 12, } 2013 \\
\text { Received in revised format } \\
10 \text { May } 2013 \\
\text { Accepted } 12 \text { May } 2013 \\
\text { Available online } \\
\text { May } 282013 \\
\text { Keywords: } \\
\text { Factor analysis } \\
\text { Market oriented }\end{array}$ & $\begin{array}{l}\text { During the past two decades, tourism industry has become popular among many researchers in } \\
\text { developing countries. Tourism is able to attract substantial amount of investment to some areas } \\
\text { where many investors are normally unwilling to invest in. This paper, presents important } \\
\text { factors influencing market orientation in tourism industry based on the implementation of factor } \\
\text { analysis. The proposed study designs a questionnaire and distributes it among } 267 \text { experts who } \\
\text { are involved in tourism industry. Cronbach alpha has been calculated as } 0.873 \text {, which validates } \\
\text { the overall questionnaire. The results of factor analysis have indicated that six factors of market } \\
\text { oriented, limiting rules and regulations, strategic competition, marketing planning culture, } \\
\text { financial figures and top management. }\end{array}$ \\
\hline
\end{tabular}

(C) 2013 Growing Science Ltd. All rights reserved.

\section{Introduction}

During the past two decades, tourism industry has become popular among many researchers in developing countries and as a results, many people have spent substantial amount of their time concentrating on the effects of various items on marketing planning. According to Webster (1988), the marketing concept has helped American businesses gain substantial positions in the world's economy. Bhuian (1998), for instance, examined the applicability of Kohli and Jaworski (1990) and Jaworski and Kohli's (1993) market orientation technique in Saudi Arabia, a developing country market by investigating a sample of 115 Saudi Arabian manufacturing firms. The properties of the scales pertaining to the constructs in the market orientation technique have been re-examined in Saudi Arabia. Further, the market orientation model was also investigated both by the traditional techniques as were used by Jaworski and Kohli (1993) and by a structural equations model in LISREL. 
Buhalis (2000) described that marketing of destinations should balance the strategic aims of all stakeholders as well the sustainability of local resources. Destinations require to differentiate their products and to develop partnerships between the public and private sector locally to co-ordinate delivery. Taking advantage of new technologies and the Internet also help destinations enhance their competitiveness through increasing their visibility, reducing costs and enhancing local co-operation. Destination marketing must lead to the optimization of tourism effects and the achievement of the strategic objectives for all stakeholders. In other investigation, Houston (1986) studied the marketing concept in a way that more clearly showed what it was and what it was not.

According to Narver and Slater (1990) business performance is influenced by market orientation, yet to date there has been no valid technique of a market orientation and hence no systematic analysis of its impact on a business's performance. Narver and Slater (1990) reported the development of a valid measure of market orientation, analyzed its impact on a business's profitability and reported a substantial positive impact of a market orientation on the profitability of both types of businesses. Kohli et al. (1993) defined market orientation as the organization-wide generation of market intelligence pertaining to current and future requirements of customers, dissemination of intelligence horizontally and vertically within the organization, and organization-wide action or responsiveness to market intelligence.

Slater and Narver (1994) investigated how competitive environment influences the strength of the market orientation-performance relationship and whether it influences the concentration of the external emphasis within a market orientation-that is, a bigger emphasis on customer analysis relative to competitor analysis, or vice versa, within a given magnitude of market orientation. Hooley et al. (2000) performed a study and stated that relationship between market orientation and both marketing strategy and performance broadly followed forecasts from the Western literature indicating that the adoption of a market orientation was equally applicable in transition as in Western economies.

Harris (2001) examined the links between market orientation and objectively measured financial performance. He reported a narrower range of environmental conditions where market orientation was positively related to performance. Wu (2004) investigated the impact of strategy and market orientation on the performance of the travel industry in a Taiwanese travel industry's electronic commerce. They reported that the marketing departments still possess influenced, and that strategy and market orientation affected performance through "customization" and "marketing influence".

Harris (2002) reported that management approaches to developing market orientation differ along five different dimensions, with each firm tending to stress one of these emphases. Homburg and Pflesser (2000) reported that a market-oriented culture could influence financial performance indirectly through market performance and that this relationship could be stronger in highly dynamic markets. Au and Tse (1995) investigated the effect of marketing orientation on firm Performance in on Hotel industry in Hong Kong and New Zealand. Greenley and Matcham (1986) investigated the marketing orientation of the firms who supply the UK's service of incoming tourism. Qu and Ennew (2003) investigated the consequences of market orientation in China. Diamantopoulos and Hart (1993) looked for the relationship between market orientation (Porter, 1990) and company performance.

\section{The proposed study}

This paper, presents important factors influencing market orientation in tourism industry based on the implementation of factor analysis. The proposed study designs a questionnaire and distributes it among 267 experts who are involved in tourism industry. Cronbach alpha has been calculated as 0.873 , which validates the overall questionnaire. The results of factor analysis have indicated that six 
factors of market oriented, limiting rules and regulations, strategic competition, marketing planning culture, financial figures and top management. Table 1 summarizes the results of our survey.

Table 1

The summary of factor analysis

\begin{tabular}{|c|c|c|c|c|c|}
\hline Factor & Measured variable & Weight & Eigenvalue & Variance & Accumulated \\
\hline \multirow[t]{5}{*}{ Market orientation } & Customer preferences & 0.845 & 3.005 & 11.129 & 11.129 \\
\hline & Industry changes & 0.712 & & & \\
\hline & Environment changes & 0.673 & & & \\
\hline & Customer information & 0.541 & & & \\
\hline & Interdepartmental meetings & 0.531 & & & \\
\hline Cronbach alpha $=0.785$ & $\begin{array}{l}\text { Sharing of customer } \\
\text { information }\end{array}$ & 0.519 & & & \\
\hline \multirow{4}{*}{$\begin{array}{l}\text { Governmental } \\
\text { Restrictive rules }\end{array}$} & Government decisions & 0.741 & 2.843 & 10.528 & 21.657 \\
\hline & $\begin{array}{l}\text { Restrictive rules posed by } \\
\text { government }\end{array}$ & 0.733 & & & \\
\hline & Restrictive policies & 0.708 & & & \\
\hline & Government intervention & 0.623 & & & \\
\hline Cronbach alpha $=0.762$ & Currency problems & 0.610 & & & \\
\hline \multirow{2}{*}{$\begin{array}{l}\text { Strategic competition } \\
\text { Cronbach alpha }=0.730\end{array}$} & Competitors’ strategy & 0.831 & 2.286 & 8.468 & 30.125 \\
\hline & Merging strategy & 0.771 & & & \\
\hline \multirow{2}{*}{$\begin{array}{l}\text { The culture of } \\
\text { marketing planning }\end{array}$} & Marketing planning & 0.824 & 2.040 & 7.554 & 37.679 \\
\hline & Business plan & 0.562 & & & \\
\hline Cronbach alpha $=0.705$ & Marketing planning culture & 0.462 & & & \\
\hline \multirow[t]{2}{*}{ Financial resources } & $\begin{array}{l}\text { Budgeting planning } \\
\text { priorities }\end{array}$ & 0.845 & 1.915 & 7.092 & 44.772 \\
\hline & Monetary promotions & 0.719 & & & \\
\hline Cronbach alpha $=0.702$ & Defensive policy & 0.465 & & & \\
\hline \multirow[t]{2}{*}{$\begin{array}{l}\text { Senior managers } \\
\text { thought }\end{array}$} & $\begin{array}{l}\text { Consistent with market } \\
\text { trends }\end{array}$ & 0.780 & 1.830 & 6.779 & 51.551 \\
\hline & $\begin{array}{l}\text { Sensitivity to the } \\
\text { performance of competitors }\end{array}$ & 0.593 & & & \\
\hline Cronbach alpha $=0.645$ & Taking risk & 0.508 & & & \\
\hline
\end{tabular}

\section{Discussion and conclusion}

Building a good market orientation is normally involved with various factors and making appropriate managerial decisions. In this paper, we have presented an empirical investigation to find out about important factors influencing market orientation in tourism industry. The proposed study gathered the necessary information by taking an indebt interview with experts. The results of our survey have resulted six factors including market orientation, governmental restrictive rules and regulations, strategic competition, existing culture in marketing planning, financial resources as well as senior managers thoughts. In terms of market orientation, customer preferences are believed to be number one priority followed by industry and environment changes. The rules and regulations posed by the local government is another barrier, which may influence development of tourism industry, significantly. The third option is associated with competition within the industry where competitors play essential role on taking market share. While the culture within the industry plays essential role on the success of tourism industry, financial resources are believed as some of the most important 
issues. Finally, Senior managers' thought is the last item, which influence this industry. The results of this survey are consistent with Kohli and Jaworski (1990) and Kohli et al. (2000).

\section{References}

Au, A. K., \& Tse, A. C. (1995). The effect of marketing orientation on company performance in the service sector: A comparitive study of the hotel industry in Hong Kong and New Zealand. Journal of International Consumer Marketing, 8(2), 77-87.

Bhuian, S. N. (1998). An empirical examination of market orientation in Saudi Arabian manufacturing companies. Journal of Business Research, 43(1), 13-25.

Buhalis, D. (2000). Marketing the competitive destination of the future. Tourism management, 21(1), 97-116.

Diamantopoulos, A., \& Hart, S. (1993). Linking market orientation and company performance: preliminary evidence on Kohli and Jaworski's framework. Journal of Strategic Marketing, 1(2), 93-121.

Greenley, G. E., \& Matcham, A. S. (1986). Marketing orientation in the service of incoming tourism. European Journal of Marketing, 20(7), 64-73.

Harris, L. C. (2001). Market orientation and performance: objective and subjective empirical evidence from UK companies. Journal of Management studies, 38(1), 17-43.

Harris, L. C. (2002). Developing market orientation: an exploration of differences in management approaches. Journal of Marketing Management, 18(7-8), 603-632.

Homburg, C., \& Pflesser, C. (2000). A multiple-layer model of market-oriented organizational culture: measurement issues and performance outcomes. Journal of marketing research, 449-462.

Hooley, G., Cox, T., Fahy, J., Shipley, D., Beracs, J., Fonfara, K., \& Snoj, B. (2000). Market orientation in the transition economies of central Europe: Tests of the Narver and Slater market orientation scales. Journal of Business Research, 50(3), 273-285.

Houston, F. S. (1986). The marketing concept: what it is and what it is not. The Journal of Marketing, 81-87.

Jaworski, B. J., \& Kohli, A. K. (1993). Market orientation: antecedents and consequences. The Journal of marketing, 53-70.

Kohli, A. K., \& Jaworski, B. J. (1990). Market orientation: the construct, research propositions, and managerial implications. The Journal of Marketing, 1-18.

Kohli, A. K., Jaworski, B. J., \& Kumar, A. (1993). MARKOR: a measure of market orientation. Journal of Marketing research, 467-477.

Narver, J. C., \& Slater, S. F. (1990). The effect of a market orientation on business profitability. The Journal of Marketing, 20-35.

Porter, M. E. (2011). Competitive advantage of nations: creating and sustaining superior performance. Free press.

Qu, R., \& Ennew, C. T. (2003). An examination of the consequences of market orientation in China. Journal of Strategic Marketing, 11(3), 201-214.

Slater, S. F., \& Narver, J. C. (1994). Does competitive environment moderate the market orientationperformance relationship?. The Journal of Marketing, 46-55.

Webster, F. E. (1988). The rediscovery of the marketing concept. Business horizons, 31(3), 29-39.

Wu, J. J. (2004). Influence of market orientation and strategy on travel industry performance: an empirical study of e-commerce in Taiwan. Tourism Management, 25(3), 357-365. 